\title{
Research on the Philosophical Classics Reading of Private College Students from the Perspective of General Education
}

\author{
Caili Yang \\ Huanghe Science and Technology College \\ Zhengzhou, China
}

\begin{abstract}
The rapid development of technology makes our life space filled with e-books. In the investigation of reading contents, almost all of the respondents chose "the interested contents". It has become micro-reading and reading ones' interested books. The lending rate of philosophical classics is ranked over one hundred in a lot of college libraries. With the popularization of higher education, private colleges and universities develop rapidly. Private colleges and universities usually are characterized by stressing technology and specialties and belittling humanities and general education. Therefore, the reading of the philosophies of humanities and social sciences mainly focuses on philosophical classics in general education. It is more and more necessary to cultivate college students, especially private college students, with humanistic spirits in general education schooling mode in modern higher education.
\end{abstract}

Keywords—general education; private colleges and universities; philosophical classics reading

\section{INTRODUCTION}

E-book is also called e-journal which is published and issued in electric version of books on internet. It can also be downloaded or received by portable reading terminal without paper, ink, transportation or inventory. It is completely a digital electric product [1]. It has characteristics of easy reading and carrying, low cost and fast publishing. E-books can fully meet reader's needs, so it prospers. Paper-made books are replaced by it to a certain extent. In the publishing circle, they are discussing whether e-books can completely replace paper-made books. This topic also relates the development trend of traditional culture. It is doubtless that the innovation of e-book reader impacts traditional culture. The report of the 5th National Reading and Purchasing Intention Sampling Survey showed that "more than $90 \%$ of netizens have ever read e-books and the netizens aged from 20 to 30 were most active" [2]. The printing culture had thousand years of history, which gives ideological enlightenment of mankind with a collision of ideas and profound culture. However, people become more and more restless in the digital era as well as culture and knowledge. The progress of technology affects all aspects of life, and human beings have lost the habit and ability of active thinking. Online bookstores have become the mainstream book buying channel. It is just an e-business platform, a cold place of technological activity. On websites of
Amazon, Jingdong and Dangdang, mobile phone and cosmetics advertising occupies the most prominent position. The situations are same on other related websites. The trend of articles of daily use becomes the development direction. On the internet books become commodities like cosmetics, clothing, mobile phones and other goods, which lost charm of culture.

\section{COllege StUdents' REAding SituATION - MicRO-} READING AND READING ONES' INTERESTED BOOKS ONLY

The author has made a survey. In the survey of "How many paper-made books do you read in a month?", 36\% of students chose "no one"; $52 \%$ of students chose "one or two books"; $12 \%$ of students chose "more than 3 books". In the survey of "What's your favorite reading mode?", 56\% of students chose "e-reading"; $28 \%$ of students chose "papermade books"; $16 \%$ of students chose "fast reading" and "voice media". If it is possible, they prefer newly emerging reading modes. Modern students lag far behind students in world famous universities in reading classics. American college students averagely read $500 \sim 800$ pages in a week. As for Chinese and foreign famous literature and professional classics, the reading quantity of domestic colleges and universities is less than 3 books within 3 months. The author has made an investigation about the cause of the popularity of e-books. $67.2 \%$ of the respondents chose "convenient to access, easy to search and reading whenever and wherever possible".

In the survey of reading contents, almost all of the respondents chose "interested contents". Toady network is so convenient and popular, and reading has become reading one's interested books. E-reading, represented by mobile phone newspaper and micro-blog, provides a huge amount of fragment and instant information, which makes reading become micro-reading. Consequently, it impairs the level and quality of reading, decrease readers' intelligence and decline readers' thoughts. Even some students dislike the long length of War and Peace and the obscure words of Remembrance of Things Past.

The majority of students say the huge block of reading classics is the long occupancy time of academic study. So, adapted movies, TV drama, contracted text, introduction to literature and other commentary become alternative of classics. 
That is why popularized readings, like Yu Dan's Opinions on Analects of Confucius and Yi Zhongtian's Thoughts on the Three Kingdoms sell good.

Shallow readings only with story and fantasy are full of affection or even abuse of affection. They are with similar contents, and like poison, poisoning reader's mind. After reading readers only get materials without any meaning. Even these contents may continue to convey wrong signals and mislead readers. If it goes on like this, readers may be addicted to this kind of readings. The shallow inspirational youth articles seem to be very positive. In fact, it involves nothing more than celebrity biographies and workplace novels. Currently undergraduate and even postgraduate regard this kind of reading as classics. The external material success is the focus of their attention, such as marriage (the dreamy unity of golden boy and jade girl), career (the gain of money). Most of them neglect spiritual growth. And the main actors and actresses are big shots, stars and commercial giants with money and status. These readings are full of cheep worldly emotions and romantic fairy tales. What is really persuasive is the success of ordinary people depending on diligence and wisdom, the will and moral character and the ability to resist frustration and setback which are meaningful for the growth of human nature. This is very similar to what Schopenhauer calls "indiscriminate reading" which may lead to unthinking mind. And Schopenhauer has warned us not to read those instantly popular books, including religious and politic booklets, novel and poetry. He severely said: "the writer writing for fools always have a lot of readers. Please don't waste your time to read these readings". He advocated to read "books written by author with great mind", for "these authors surpasses most of people and their voices are worthy of our listening to".

\section{The PRoblem In College STUdENTS' READING - PutTING PhILOSOPHICAL Classics SHELVED}

The philosophy of classical texts fervently concern primitive characters and universality. It leads readers to reflect themselves, understand and recognize the world. They are real spiritual nourishment. Therefore, classic reading of philosophy is completely different from "shallow reading".

In Why Do We Need to Read Classics, Italy Writer Calvino earnestly warned: "classics are books which can provide previous experience to people who read and like them"; "every time you reread classics, it likes the first time. It is a journey of discovery. Classics are things which could degrade current interests as background noise". Strauss said even more simply: "people of our era have been unable to talk with the ancients, so we couldn't receive edification and teaching through listening to their patient and skillful words. Meanwhile people don't know whether it can produce 'the great mind' in their words in this noisy era. Even it is possible, how many people could happily meet it in classroom and reality. Fortunately, the words of 'the greatest minds' are open to people today. So we can only meet these minds in the crystallization of the wisdom - 'great books' [3]". Classics are the great books.

However, the report of book retail market showed that books of Guo Jingming and Han Han ranked at the top five in e-book sales in 2012. The lending rate of philosophical masterpiece is ranked over 100. Books are replaced by network reading, even micro-blog and Facebook. The philosopher Jaspers lamented people read hastily, pursue fast obtained, short and quick forgotten information and abandon reflective things, so college students' reading is. Social restlessness and shallowness reflect the atmosphere of "shallow reading".

\section{The Consistent Purpose Of Private Colleges AND UNIVERSITIES}

\section{A. The Development Status of Private Colleges and Universities}

1) The development status: The development of society has promoted the popularization of higher education. Private colleges and universities have taken the advantage of this opportunity and developed. As of the end of 2011, there were more than 1,400 private colleges and universities in our country. Among them there were 390 universities (303 independent institutes and 87 general institutes of higher education). It has increased by 16 universities in 2011 than in 2010. In 2011 the number of recruitment students reached $5,000,000$, increased by 330,000 than in 2010 . On the level of running schools, 17 independent colleges have transformed into independent universities [4]. In the national special talents cultivation project pilots, five private universities and Beijing city colleges got the master's degree enrollment qualification and achieved a new breakthrough. It was the first time for private institutes to get graduate education qualification since the foundation of the PRC. The diploma level of private colleges and universities was further promoted, which marked the monopoly of public institutes and universities was broken in recruiting graduate students. In quality of schooling, it no more cares about scale like past but internal construction. High quality is the new tendency of private universities who set schooling characteristics and level as their middle or long-term goal. Compared with the conditions (with no money, teachers and school buildings) in past ten years, private schools pay more and more attention to improve education quality and campus culture construction. Compared with public schools, private schools pay more attention to innovation of talent cultivation mode and schooling characteristics. They respect, encourage and develop students' interests and hobbies.

2) Stressing technology and specialties and belittling humanities and general education: However, the completion of higher education becomes increasingly fierce. With sharp decline of student source, private colleges and universities faces severe challenges as well as new opportunities. "Private colleges and universities should have their own fresh characteristics; otherwise, it is difficult for them to survive." Therefore, most of private colleges and universities use the mode of characteristics and hot specialties in their talent cultivation standard [5]. In the layout of professional disciplines, private colleges and universities prefer to set specialties of engineering and technology. In order to help graduate adapt fierce employment competition and scale merit, private colleges and universities generally stress professional and technological courses in the curriculum. They increase hours of professional courses and reduce hours of English, 
politic theory and other public courses. On the one hand, it is because the non-obvious role of these courses. On the other hand, these courses seem to be not recognized in employment. So it becomes the schooling characteristics of private school to stress technology and specialties and belittle humanities and general education. It is also the reason why most of private colleges descend to vocational training institutes.

\section{B. Transformation, Beginning to Attach Importance to General Education}

The private education promotion law and its regulations were implemented on April 1, 2004, which has supported and encourage the development of private schools to a certain extent. It facilitates the development of private education and provides policy support for it and regulates the management of private education through policy. With legal ground, private education becomes more and more strict and standard.

For a long time, pragmatism has plagued the reform process of China's higher education. On the one hand, it expands the college enrollment but lowers the objective quality of students. On the other hand, many students have the thought of stressing science and belittling arts, and pursue to grasp applied technologies. They neglect knowledge of humanities and social science. They perceive and appreciate things with rational eyesight, and disciplines of humanities become more and more marginalized. In addition, the double-edged sword of science and technology, such as video entertainment and eproducts, makes students lose interest on knowledge and make them become restless and irritable. Students forget the most basic ethical norms and social responsibilities. President of University of Hong Kong Jin Yaoji said: "the cultural meaning of college education is to cultivate students' humanistic value and help them set the order of human in the universe right." [6] the Several Opinions on Enhancing College Students' Cultural Quality, the Ministry of Education clearly puts forward that "it is aimed to promote students' cultural taste, aesthetic taste, humanistic quality and scientific quality by educating them about literature, history, philosophy, arts and humanistic and social sciences". Science education is very necessary for college students, as well as humanistic education. Therefore, it is very important for students to read philosophical classics and increase readings of philosophical classics about humanities and social science. It has become a trend for modern higher education, especially private colleges and universities, to use the schooling mode of general education to cultivate students with humanistic spirit. And some colleges and universities have emphasized the importance of general education.

\section{Philosophical Classics Concerning People}

What kind of person one will be depends on what he/she reads. Some books seem to be useless when you read it, but many books in the world are for interest and fun, and they may be irrelevant to utility. Some books have a distance from reality. But in another perspective, it is the nearest to our ideal. Some books may help us a little, but they may influence us lifelong.

\section{A. The Significance of Philosophical Classics}

It not only can cultivate students' with high reading taste, but also develop students' personality trait to read philosophical classics. The so-called chicken soup for our soul may frame our sight if we are too satisfied about it.

Western philosophy emphasizes "to establish the truths", while Chinese philosophy stresses "to build personality". The origin of force of traditional classical philosophy is to reveal the terminal mystery of man and the world. In the languages of philosophical classics we can feel a strong sense of consubstantiality of man, mankind and universe. It has the spirit of glancing at the sky and also stresses the settlement of person on the earth. Its persistence and enthusiasm for both of them help us abandon selfishness and strive to pursue the harmony of all human beings, which best expounds the dignity of people. Philosophical classics, as a treasure of knowledge, have the meaning of paradigm, so we should read them carefully. It stresses the self-verification and free existence of subject, similar to the essence of literature and art. Literature and art interpret life with image and art, while philosophical classics explain our life with abstract ideas. "The cosmic order" is the discussion point of philosophy, and "the life order" is the end of philosophy. We should admit that philosophy explain the existence and appearance of subject with moderate attitude and sharp version. It is not satisfied with the narrative description but good at examination and reflection. Its primitive questioning is far better than science, so it could perfectly reflect the thinking of subject. If answer is the result of science, the question is the entrance to philosophy.

The nature of the world and the foundation of human nature are the direction of the classical art and the humanistic classics. But the achievement of art depends on the accumulation of humanistic quality. Art stresses to be expressed with emotions and stories. Balzac's "I destroyed every obstacle" was replaced by Kafka's "Every obstacle destroys me". It cannot explain the change of these two sentences only with literature, for it has profound philosophical meaning. Philosophy doesn't only represent the idea of author, and it points to distance. So, to comprehend classics relates the benefit of reading.

Confucius said that it is important to know one's own limitations. But it is the most difficult for us to know ourselves. So, "to know oneself is wise". "To know oneself" become an eternal problem confronting people in the west and east. To a large extent to read philosophical classics could help us know ourselves, for these classics devote themselves to pick and analyze all hypocrisies and false and profoundly pursue the nature of human. It helps readers find true self and reflect themselves and stimulate self-awareness, and thus readers may produce the thought of serving people as their duty and extensive social care. In this sense, Roman Rolland said: "no one reads for reading but for finding oneself and examining oneself". Proust said "the reading process is a process of communication and a soul talk to an absent or dead author". It emphasizes to truly understand oneself by book-to-man conversation. 


\section{B. How to Read Philosophical Classics}

1) Slow reading: Modern world lacks mutual understanding and it is not easy to understand classics. And to an extent they don't conform to "micro-reading" standard. To read classics, first readers should be calm down and read them with admire and patience. Readers could play their own intelligence and feelings, and walk into the book to understand and think. Slowly readers could develop an elegant interest.

Readers should overcome the psychology of seeking fast in reading. In the calm and contemplative reading process, words in classic text seem to be alive in readers' mind. Because of readers, the value of these words is increased and extended. So, readers should avoid reading classics fast, but slow down and immerse themselves in book to gain the precious experience through the book and feel favorable or unfavorable turns that they could never experience in the ordinary life. If readers couldn't calm down, read carefully and savor slowly, they may not understand authors' yearning.

"Slow reading" is a good method to read classics. At same time readers should keep quiet and clam. Previously readman always carried such an attitude to read books. Chinese ancient scholars were fond of leisure and quietness. The wise always could clam themselves down, which is also the same in the west. Only by surpassing the mentality of utility and be at ease, could man really read and understand the pure true essence in the world. So, readers could experience the long lost fun in reading classics slowly.

2) Selecting excellent works: Philosophical texts, such as Utopia and Being and Time, truly concerning over man and profoundly caring about the destiny of mankind in the world can be called as classics. Presently fashion overturns classics and readers abandon traditional dignity. College students are immerged by overturning "cultural fast food". Good reading habit has gone far gradually. Regardless of swotting up before final exam, college students seldom read books. Some of them may use very limited time to read classic works. Even they have heard the name of these classics, but they wouldn't select them. They may prefer to select some funny or spoof text for relaxation. Diminishing value and gaming life and even relativism fill network, which ruins the college students' taste in reading. So, we should keep away from the risk that may ruin our life. College students should develop a habit to read books frequently and read excellent works and classics, which is to lay a foundation for life.

3) Reading method: When we read philosophical classics we should pay attention to several points. First, understand knowledge. Second, enlighten thinking. Readers should question a lot in reading, and could seek and find relevant works to make a primary research. Third, the most important is to perceive self-restraint. Readers should read in the blending of sensibility and sense. Withdraw from meaning and wisdom in classics and reset the relationship of self and the world.

There is no need to worry about not finishing reading of philosophical classics. Reading is a lifetime thing, and reading philosophical classics is especially important. At same time to learn by analogy and infer other things from one fact is also very essential in the process of reading philosophical classics.
It is also no need to worry about not understanding the content. It provides us knowledge and hopes compared with shallow things we prefer.

Qi Jiguang said the best way to develop good character is to improve one's quality; the best way to get fun is to read. The reading atmosphere is declined, but charm of classics never decays. And we could only see it in reading. In modern society, the loathsome business makes us alone even we live in groups. Reading enables us to communicate with great men without worrying about disturbing any one and without greetings. Time is long, and to some extent, to read what kind of books determines what kind of person you will be. Anyone who doesn't read or read without selection would become a vulgar person.

\section{CONCLUSion}

As the core concept of modern college education, humanistic spirit not only runs through the humanities education in colleges and universities, but also plays an important role in the construction of higher education. Mr. Qian $\mathrm{Mu}$ believes that the humanistic spirit of college education should be reflected in the three "consciousnesses", namely "moral consciousness, ideal consciousness, cultural consciousness" [7]. This point of view explains the concrete connotation of humanistic spirit. By reading philosophical classics college students could educate themselves with humanistic aesthetics, and understand the connotations of human history and culture in philosophical terms. The humanistic spirits of authors in classics may be passed down, and college students could learn moral self-discipline and obtain healthy and ideal sentiment and independent personality, and become more brave and vigorous. Therefore, colleges and universities should attach importance to the construction of humanistic spirits in general education. To read philosophical classics could help promote humanistic spirit education, and help us inherit historical humanistic civilization and construct modern ethnical culture, so that we could cultivate new talents with innovative and enterprising spirits and the inner power of humanistic spirit could be showed. Therefore, reading of philosophical classics plays an important role in the cultivation of humanistic spirit. With rapid development of economy, our higher education lacks the cultivation of students' humanistic spirit. To read philosophical classics could change this situation and help run through the people-oriented education concept in modern education and improve students' morality and social responsibility. In the overall goal, we could take philosophical classic aesthetic appreciation to guide students to think about life, history and culture and complete personality shaping. The speeding development of technology and economy brings us fast-food cultures, so we should adjust our higher education and made innovation to adapt to our society. The new development mode of modern education has become an approach to realize the interaction of professional education and general education. So, only by blending humanistic spirit and scientific knowledge, students could accumulate scientific knowledge and have a broad humanistic mind. 


\section{REFERENCES}

[1] Yan Li. E-book: Cannot But Blame You. Library Theory and Practice, 2004 (2).

[2] Li Miao. Micro-reading Becoming a Hit and Online Reading Overtakes Our Life. China News Publishing, 2009 (4).

[3] Wang Yonghao. Why Should We Read the Classics. Study, 2012 (10).

[4] http://www.233.com/gaokao/zixun/dynamic/all/20120531/155046915.ht $\mathrm{ml}$

[5] Ke Youxiang: Investigation and Analysis of the Status Quo of the Development Positioning of Private Colleges and Universities in China, Higher Education Research, 2012 (10)

[6] Jin Yaoji. Concept of University. Beijing: Sanlian Publishing House, 2001: 45 .

[7] Qian Mu. China Academic General. Taiwan: Taipei Student Press, 1977: 225 